\title{
The Hebrew of the Ben Sira Manuscripts from the Genizah
}

\begin{abstract}
The Genizah manuscripts of Ben Sira contain a layer of Hebrew writing composed from scratch in the Middle Ages, as well as some phrases created by medieval copyists unfamiliar with the Second Temple Hebrew of their Vorlage. When these secondary elements are sifted out, to the extent they can be, one is left with a text whose language is still remarkably diverse. The present article presents an attempt at categorizing linguistic phenomena characteristic of this variety.
\end{abstract}

Keywords: Ben Sira, Biblical Hebrew, Cairo Genizah, linguistic diversity, Postbiblical Hebrew

\section{Introduction}

When fragments of Ben Sira from the Cairo Genizah were first published, they were hailed as the remains of the lost Hebrew original. But not everyone was convinced of their authenticity. Famous Semitists found the Hebrew of the new manuscripts unconvincing and preferred to view the texts as medieval retroversions from Syriac, Greek or Persian. ${ }^{1}$ The debate dragged on for some decades. In an article published in 1955, the great Hebraist H. L. Ginsberg stated that if ever pre-Arab Hebrew manuscripts of Ben Sira should come to light they would be found "to be as unlike $\mathrm{H}$ [i.e. the Cairo manuscripts] as imaginable." ${ }^{2}$ The discovery of the Masada fragments nine years later, in 1964, laid this claim to rest. The Masada Scroll (Mas), dated to the first century CE at the latest, differs only in details from Genizah manuscript B, although the manuscripts are separated by around a thousand years. Since the publication of Mas, almost all Hebrew scholars have accepted that the Genizah manuscripts are for the most part not to be understood as back-translations, but that they descend by scribal transmission from the original Hebrew work. ${ }^{3}$

1 See Torrey, “Genizah Sirach,” 22-23; van Peursen, Verbal System, 57-59.

2 Ginsberg, "Original Hebrew."

3 The hypothesis that the texts go back to manuscript discoveries in the Judean desert in the eighth century, defended by Alexander Di Lella and others, is attractive, although it cannot be proven definitively: see Di Lella, "Qumran." 
An example will illustrate the value of Mas in authenticating the Genizah manuscripts, while demonstrating some of the problems involved:

Sir 41:14

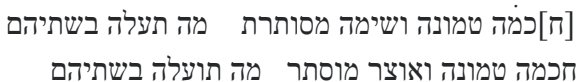

Mas

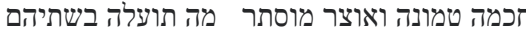

Hidden wisdom and concealed treasure, what is the use of either of them?

There is some variation between the two texts. The orthography is slightly more defective in Mas. In addition, the texts use different words for "treasure": Mas has שימה, a postbiblical word borrowed from Aramaic, while B reads the biblical אוצר. The grammar suggests that the reading of Mas is the original one, since B's reading creates a somewhat jarring lack of grammatical gender concord between the two hemistichs. Not too much weight should be accorded to this, however. Similar cases of word-substitution occur also between the Genizah manuscripts, and sometimes even between readings included in one and the same manuscript. Note that סימה (though written with samek, not sin) is found in a marginal reading in B to this verse: וסימה מסותרת glossing ואוצר מוסתר.

The example documents how Mas typically confirms B, with a few divergences that are not easy to explain. Although Mas is the older manuscript, the more primitive text form is not always found there. Linguistic variation seems to be bound up in the textual transmission of Ben Sira almost from the start.

\section{Medieval Hebrew in the Genizah Manuscripts}

The basic authenticity of the Genizah manuscripts does not mean that, as Israel Lévi wrote around the turn of the twentieth century, "in the main the work of Ben Sira has been preserved just as it left his hands." ${ }^{4}$ All the Genizah manuscripts exhibit corruptions and mistakes, some obvious and some almost impossible to fathom. To linguists, these defects are a nuisance, but they do not really interfere significantly with their work. An erroneous reading, or a suspect one, may be disregarded:

Sir 7:3a (A)

The Greek and Syriac versions here have something like: "do not sow on furrows of unrighteousness," a thought that fits well the second hemistich: "lest you reap it sevenfold." How A's text came into being, and what the scribe thought it meant, is hard to say. ${ }^{5}$

4 Lévi, "Sirach,” 389-90.

5 See also, e.g., Sir 4:14b A; 32:12a B, F. 
More difficult to handle are cases of intentional updating and rewriting. In 41:14 quoted above, שימה and אוצר are synonyms drawing on distinct language systems: אוצר is the usual word for "treasure" in BH, while שימה is a loanword from Aramaic, unattested in Hebrew texts before the Hellenistic age. ${ }^{6}$ The variation is not due to a scribal mistake, but to conscious reformulation: either "modernizing" (שימה ד אוצר), or "reclassicizing" (אוצר ד שימה); - deciding between these alternatives is difficult. The change may have been made by scribes, but it may conceivably go back to variant editions created by the author or his entourage.

In some instances, entire verses or half-verses are transmitted in two different versions, one closer to biblical diction, the other more representative of Postbiblical Hebrew: Sir 4:31

אל תהי ידך פתוחה לקחת וקפוצה בתוך מתן

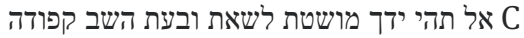

Let not your hand be stretched out to receive and closed when it comes to giving.

The diction of A is close to Deut 15:7-9, while C has markedly later vocabulary: נשא "to receive” (instead of הושיט "to stretch out," קפד "to contract” (probably an Aramaism, although the root is attested in Isa 38:12).

The phenomenon of doublets has been much discussed. Until the 1970s, most scholars thought the general drift in textual history was from a more biblical style to a more popular type of proto-Mishnaic diction. The publication of the Masada Scroll suggested, however, that the evolution might sometimes go in the opposite direction: while B has the biblical אוצר, Mas exhibits the distinctly postbiblical שימה. There are several other examples of this constellation. This has led some to a different opinion: the original text may have been written in a postbiblical idiom that had developed in the time of Ben Sira, while biblicizing diction was introduced by later scribes. This is an interesting suggestion. It explains several divergences between Mas and B, but it cannot serve as a general theory. Note the following doublet: Sir 30:17

טוב למות מחיי שוא ונוחת עולם מכאב נאמן B1

To die is better than to lead a worthless life, and eternal rest than constant pain.

טוב למות מחיים רעים ולירד שאול מכאב עומד B2

It is better to die than to lead a bad life, and to descend to Sheol than to suffer constant pain.

The doublet here is transmitted in the text of MS B. As has been recognized by several scholars, the notion of "descending" in $\mathrm{B}^{2}$, expressed by means of the typ-

6 The word is attested in Hebrew Tobit at 4:9 (4Q200 2:9) and in the Words of the Luminaries (4Q504 7:9). 
ically Mishnaic infinitive נירד, stems from a misinterpretation of נוחת "rest" on the basis of the Aramaic root נחת "to descend." This almost certainly means that the second reading is a secondary reformulation. One can explain how the second version was created out of the first, but not vice versa. In this verse, the later Hebrew represents a secondary reformulation.

In most doublets, however, it is difficult to prove the priority of one version over the other. The best solution is probably to reject global theories and to accept that rewriting could have gone in different directions: an opaque biblical word or expression might have been modernized, and a late Aramaicizing word or expression could have been reformulated in Classical Hebrew. Both processes seem to have affected the textual history from an early stage.

Some of the doublets were explained by Israel Lévi as retroversions on the basis of the Syriac version. This approach is possible, and would explain some very puzzling expressions in the Genizah manuscripts. As van Peursen has shown, however, the Syriac retroversion theory does not solve all the problems it seeks to address and the question must remain moot. ${ }^{7}$ There is nevertheless one exception: the retroversion theory is widely accepted for the Psalm in Sir 51:1330 , where it works over a longer stretch of text and where manuscript B diverges widely from the Hebrew version contained in the Psalms Scroll from Qumran (11Q5). Thus the use of the demonstrative pronoun אילו "these," a Mishnaic equivalent of אלה (used in all other instances in Ben Sira), may safely be regarded as secondary in 51:24.

\section{Linguistic Variety}

The Genizah manuscripts contain a thin layer (including all of 51:13-30) of Hebrew writing composed from scratch in the Middle Ages, as well as some phrases created by medieval copyists unfamiliar with the Second Temple Hebrew of their Vorlage. When these secondary elements are sifted out (to the extent they can be identified), one is left with a text whose language is still, in diachronic perspective, remarkably diverse. Let us try to identify some prominent features. ${ }^{8}$

7 Van Peursen, “Alleged Retroversions."

8 In what follows, Biblical Hebrew will be used as a standard against which to measure Ben Sira's language. The procedure is problematic for many reasons: the biblical corpus is itself very diverse, and "Biblical Hebrew" is arguably not a language at all, but a conglomerate of various dialects and chronolects. The distinction between "Classical" $(\mathrm{CBH})$ and "Late" Biblical Hebrew (LBH) mitigates this objection, but only to a certain extent. $\mathrm{LBH}$, in particular, is itself rather 


\subsection{Late Biblical Hebrew}

Ben Sira shows clear alignment with "Late Biblical Hebrew": the language of Chronicles, Ezra-Nehemiah, Esther, Daniel and Qoheleth. ${ }^{9}$ Many words attested in the Bible only in these books also make appearance in Ben Sira: ${ }^{10}$

"to force” (Sir 31:21; Esth 1:8)

ir "kind, sort” (Sir 37:28; Ps 144:13; 2 Chr 16:14)

ישט hiphil "to stretch out" (Sir 4:31; 7:32; 31:14, 18; Esth 4:11; 5:2; 8:4)

"knowledge” (Sir 3:13; 13:8; Eccl; Dan; 2 Chr)

בבואה "prophecy” (Sir 44:3; 46:1, 13, 20; Ezra; Neh; 2 Chr)

סוף “end” [noun] (Sir 8:18; 11:27; Joel; Eccl; 2 Chr)

"word” (Sir 5:11; 8:9; Qoh 8:11; Esth 1:20)

צרך "need” (9 x Sir; 2 Chr 2:15)

שרביט “scepter” (Sir 37:18; Esth 4:11; 5:4; 8:2)

And note the following grammatical features:

לאין “without” (Sir 51:4; Ezra 9:14; 12 Chr)

piel forms of hollow roots (Sir 8:6 בוג 13:23; many times in LBH [קוב , שום)

יותר adverb “more” (Sir 3:23; 10:27, 31; 7 x Eccl; Esth 6:6)

עם with infinitive in a temporal meaning (Sir 38:23; 40:14; Ezra 1:11)

בכן “then” (Sir 13:7; 32:2; Qoh 8:10; Esth 4:10)

"to find to be” (e.g. Sir 46:20, "he was found intelligent”; Neh 9:8 "you found his heart faithful").

All these features likely emerged in Hebrew during the Babylonian or Persian periods at the earliest. They are not old inherited terms unattested only by accident in the older biblical books. Many of them are borrowed from Aramaic, and some from Persian (פתגם , זן). In the Bible they are strictly limited to the LBH corpus. For most of them, a "classical" BH counterpart is attested (e.g. סוף "end" in LBH corresponds to "לאין "end" in classical Hebrew; "without" corresponds to בלי "without").

The LBH features do not demonstrate that Ben Sira was particularly fond of the late books of the Hebrew Bible. Rather, they reflect the literary Hebrew fashionable in his time. The earliest samples of LBH may go back to the fifth century (notably parts of Nehemiah), but much of the LBH corpus is closer in time to Ben

diverse. Yet it is important to start somewhere. The results of the approach will, it is hoped, help justify it.

9 Kutscher, History, 88. For the definition of LBH, see Hurvitz, Lexicon.

10 No effort has been made to be exhaustive. 
Sira (and the Hebrew parts of Daniel are later than Ben Sira). LBH and Ben Sira overlap and therefore naturally exhibit some of the same linguistic features.

\subsection{Postbiblical Hebrew}

Other late words in Ben Sira-again, most of them borrowed from Aramaic-are not found in LBH. Note the following: ${ }^{11}$

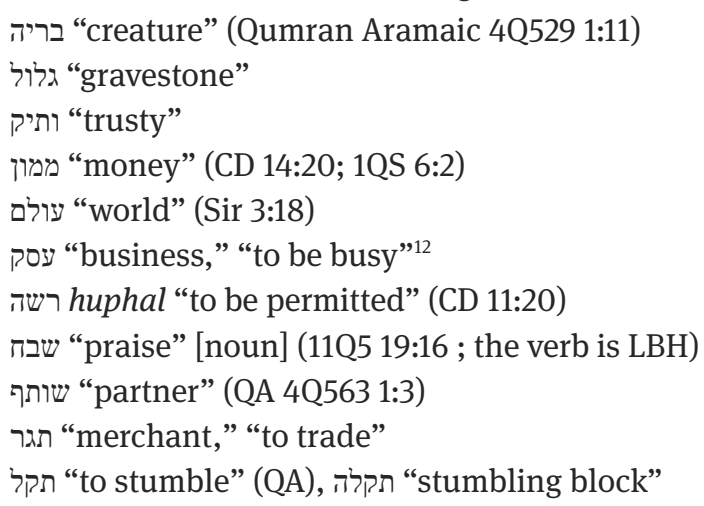

All of these words are well known from Mishnaic Hebrew, but absent from the biblical corpus and, except where indicated, absent from the Qumran texts too. ${ }^{13}$ Note also the following items of grammar:

אין with suffix pronoun in a nominal clause whose predicate is a substantive (Sir 50:25)

כיוצא בו "as befits him” (Sir 38:17; cf. 10:28)

Some of these features are no doubt absent from the Hebrew Bible simply because there was no occasion to use them. The LBH authors who used the verb שבח "to praise" presumably also knew the noun שבח "praise.” But most of these features would seem to have emerged in Hebrew too late to be used in the LBH books.

11 Again, no effort has been made to be exhaustive. For an exhaustive list of lexical innovations in Ben Sira, see Dihi, "Innovations."

12 The word is also attested at Sir 7:25 with the meaning "strife," which is found in the Hebrew Bible written with sin, rather than samek (Gen 26:20: עשק (ע)

13 It is surprising to observe that Ben Sira has no indisputable Greek loanwords. At Sir 47:15 Lévi and the edition of the Hebrew Academy read ותקלס' במרום שירה, thus seemingly attesting the Greek loanword קלם בלט "to praise." Others read the word as. 
Conversely, one or other of these elements may reflect the Hebrew of medieval scribes. ${ }^{14}$ However, as a type, these postbiblical features are far too prominent in all the Ben Sira manuscripts to permit an attribution to medieval rewriting. The correct evaluation of these items seems to be that they demonstrate the book's relative age. Ben Sira is later than most LBH books and uses a more evolved type of Hebrew.

\subsection{Reclassicizing}

While the elements enumerated in the preceding sections lend the texts a distinctly postclassical flavor, one also finds many classical features in Ben Sira. As a rule, the classical counterpart occurs alongside the late features: apart from LBH סוף “end,” one also finds CBH קץ "end,” and, in addition to "sort,” one also finds the earlier synonym מין

One might argue, perhaps, that the joint presence of purportedly "biblical" and "postbiblical" elements in Ben Sira is simply indicative of the age of the book: earlier features are giving way to later features, but have not yet entirely disappeared. However, this view cannot account for all classical features occurring in Ben Sira. Some of the classical features require a different explanation.

A striking phenomenon is the presence of classical features never encountered in Late Biblical Hebrew. A good example is the particle פן "lest." This particle is found 85 times in $\mathrm{CBH}$ and 48 times in other books of the Hebrew Bible, but only once in $\mathrm{LBH}$, in a passage the Chronicler copied from 1 Samuel (1 Chr 10:4 // 1 Sam 31:4). Such a distribution suggests that the particle became obsolete in the Babylonian period and was no longer actively used after the return from exile. The grammatical function of פן was expressed with other particles (notably

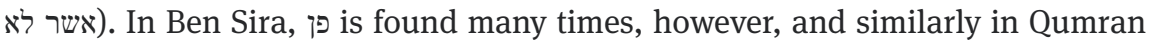
Hebrew. Several other items have a similar distribution, notably טרם "before," אולם "all the more so.”

The distribution of these features seems to indicate a kind of revivification of classical forms of Hebrew in the Hellenistic period. Having studied the scriptures intensively, the later author feels entitled to reuse words and expressions that he found there even if they are no longer part of the living practice of Hebrew.

14 Above we noted that the demonstrative אילו "these" in Sir 51:24 almost certainly reflects medieval composition. The infinitive לירד in 30:17, the only one of its type (based on the form of the imperfect in weak verbs) in the entire book, was also revealed to belong to a secondary layeralthough not necessarily post-Second Temple. For other possible examples of Medieval Hebrew, see Segal, “Language,” 109-12. 
Possible confirmation of this hypothesis can be found in some surprising differences between the usage in Ben Sira and the earlier one found in the biblical books. In $\mathrm{CBH}$, פן is, like all modal particles, invariably constructed with the "long form" of the imperfect: one says "les "lest you bring up," never פן תעל In Ben Sira, the short form (or jussive) occurs twice: Sir 7:3b

פן תקצרהו שבעתים

...lest you reap it sevenfold. ${ }^{15}$

The long form would be תקצרנו here; suffixes with he represent the short form. ${ }^{16}$ Although this may be a copyist's error, it more likely shows us a Hebrew author of the Hellenistic period striving to write good classical Hebrew but slipping up while he does so.

\subsection{Pseudo-classicisms}

This brings us to the phenomenon of pseudo-classicism. ${ }^{17}$ In several passages in Ben Sira, the manuscripts attest words and expressions whose scriptural provenience is clear, but whose usage diverges in a way that suggests some form of reanalysis. In an earlier publication, I pointed to the expression שים, which in Biblical Hebrew always refers to two parts of a larger whole (e.g., Deut 21:17, on the heritage of the first-born), but in Ben Sira is used twice in the meaning "double, twice as much." As it appears, the classical expression fell out of use, and its meaning was forgotten; it was then "recovered" (falsely) on the basis of close study of the passages in which it occurs. Pseudo-classicisms are found also in $\mathrm{LBH}$, where they are rare, and in Qumran Hebrew, where they are very numerous.

Identifying pseudo-classicisms in Ben Sira is tricky, because the author likes to play with his intertexts, and divergences in meaning or form may in some cases be intentional.

Sir 11:4

AB

Do not scoff at the ones whose day is bitter.

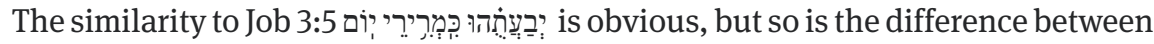
the two passages: while in Job the lexeme is kimrir(im) "darkness (?),” Ben Sira

15 The other case of a short form occurs in 30:13 Bmg, after the פן in Btxt.

16 Joosten, Verbal System, 12.

17 Joosten, "Pseudo-classicisms." 
reflects reanalysis as ke + merirey (so also the Rabbinic Targum to Job 3:5: היך מרירי יומאץ). It may be that Ben Sira knew the correct analysis of Job 3:5 but decided to use the phrase differently. But it is equally possible that he did not know it, and that his erudite intertextuality is based on a "wrong" understanding.

Several other instances of pseudo-classicism may be pointed out:

in a sense based on the noun מהתמהמה in Sir 12:16

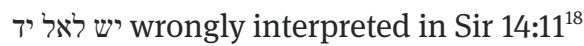

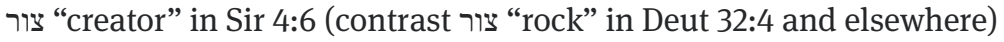

"עזב "to pardon” as antonym of עזב "to "to "to "tondon" in Sir 3:13 (contrast help” in Exod 23:5).

These instances situate Ben Sira on a trajectory leading from LBH to QH. During the Hellenistic period, literary Hebrew manifests a growing tendency to reclassicize. Literati made a concerted effort to understand Biblical Hebrew better and to follow it as much as possible in new religious compositions.

\subsection{Ancient Hebrew Vocabulary and Phraseology not Borrowed from Scripture}

Although much of Ben Sira's Hebrew is markedly late, and some of it reflects artificial reclassicizing, the book also transmits some early forms of Hebrew not found in the Bible (at least not in the version we know). A good illustration is the following description of snowfall: Sir 43:17b

Mas B

(Mas) like locusts settling is its descending

(B) like locusts settling on their dwelling

The simile is reminiscent of a passage in the Ugaritic epic of Kirta, in the description of a military campaign: CAT 1.14 IV 29

$k m$ irby tškn šd

"like locusts settling on the steppe"

Both the syntax of the simile, and the semantics of the verb שכן, suggest that Ben Sira is here following an earlier pattern-not Kirta, of course, but a similar composition containing the phrase.

18 Joosten, “Pseudo-classicisms,” 154-55. 
Other indications of Ben Sira's independent knowledge of ancient Hebrew are his use of old words unattested in the biblical corpus: note אשיח "reservoir" (Sir 50:3), attested in the form wשוח in the Mesha Stele (KAI 181 1:9), and probably also עצה ערק hiphil "to shine" (Sir 43:9; 50:7). ${ }^{19}$ Admittedly, it is not always possible to tell whether words found in Hebrew only in Ben Sira are originally Hebrew or borrowed from Aramaic.

\section{Evaluation}

Most scholars who have tried to explain the linguistic diversity present in the Ben Sira manuscripts have attributed it to the presence of various hands: later rephrasing of classical expressions (and entire verses) in a more modern idiom, or conforming of Ben Sira's proto-Mishnaic diction to a more biblical style, or haphazard modification in multiple stages. The enumeration of features attempted above suggests a different view. Most of the diversity exhibited in the manuscripts would appear to be representative of the type of Hebrew that would have characterized the ancient work itself.

The tension between a more classicizing style close to what we find in the Hebrew Bible and a more modern idiom heavily tainted with Aramaic and Mishnaic elements is found also in the late biblical books, and in different proportions in the Qumran texts as well. Even alternative readings such as שימה/אוצר in Sir 41:14, and doublets such as one finds in 4:31 and 30:17, are not necessarily to be attributed to later scribes. Some of the alternative readings may reflect variant editions composed during the lifetime of the author. Another possible source of textual variation is the oral-written nature of the educational setting presupposed throughout the work: Ben Sira may have written down one version of a proverb in his book and used another one in his oral teaching. Perhaps oral translation too played a role: the easiest way to explain the meaning of Ben Sira's difficult Hebrew would have been to translate it into another language-most likely Aramaic.

These are mere speculations, of course. The linguistic evidence as it is cannot prove that the text of the manuscripts in the main goes back to antiquity. What may be said, however, is that with a few notable exceptions (such as eylu in Sir 50:24) the language of the manuscripts does fit with what we know about the Hebrew language of the period when the book was produced.

19 Again, no effort to be exhaustive has been made. 


\section{Bibliography}

Dihi, Haim. "The Morphological and Lexical Innovations in the Book of Ben Sira." PhD diss., Ben-Gurion University of the Negev, 2004.

Di Lella, Alexander A.. "Qumran and the Geniza Fragments of Sirach.” CBQ 24 (1987): 245-67. Ginsberg, Harold L. "The Original Hebrew of Ben Sira 12:10-14.” JBL 74 (1955): 93-95.

Hurvitz, Avi. A Concise Lexicon of Late Biblical Hebrew: Linguistic Innovations in the Writings of the Second Temple Period. VTSup 160. Leiden: Brill, 2014.

Joosten, Jan. "Pseudo-classicisms in Late Biblical Hebrew, in Ben Sira, and in Qumran Hebrew." Pages 146-59 in Sirach, Scrolls and Sages. Proceedings of a Second International Symposium on the Hebrew of the Dead Sea Scrolls, Ben Sira, and the Mishnah, Held at Leiden University, 15-17 December 1997. Edited by Takamitsu Muraoka and John F. Elwolde. STDJ 33. Leiden: Brill, 1999.

-. The Verbal System of Biblical Hebrew. A New Synthesis Elaborated on the Basis of Classical Prose. Jerusalem: Simor, 2012.

Kutscher, Eduard Y. A History of the Hebrew Language. Jerusalem: Magnes, 1982.

Lévi, Israel. "Sirach, The Wisdom of Jesus the Son of." JE XI:388-97.

Peursen, Wido Th. van, "The Alleged Retroversions from Syriac in the Hebrew Text of Ben Sira

Revisited: Linguistic Perspectives," KUSATU 2 (2001): 47-95.

-, The Verbal System in the Hebrew Text of Ben Sira, SSLL 41 (Leiden: Brill, 2004).

Segal, Moshe Z. "The Language of Ben Sira." Leshonenu 7 (1936): 100-120. (Hebrew)

Torrey, Charles C. "The Hebrew of the Geniza Sirach.” Pages 585-602 in Alexander Marx Jubilee Volume. Edited by Saul Lieberman. New York: Jewish Theological Seminary of America, 1950. 
Brought to you by | Cambridge University Library Authenticated Download Date | 2/7/19 7:31 PM 